\title{
¿Existe envejecimiento precoz entre los consumidores de drogas de abuso?
}

\section{How bad is accelerated senescence in consumers of drugs of abuse?}

| FÉlix CARVALHo

\section{RESUMEN}

El proceso de envejecimiento que sigue a la madurez se caracteriza por una decadencia funcional vinculada a la edad y cuyo origen es la degeneración anatómica, fisiológica, bioquímica y genética de los tejidos y de los órganos. El daño oxidativo del ADN mitocondrial (ADNmt) en el corazón y el cerebro es inversamente proporcional a la longevidad máxima de los mamiferos, lo cual indica que la acumulación de daño de ADNmt participa en diversas enfermedades relacionadas con el envejecimiento, el cáncer y la neurodegeneración. La menor proliferación de células madre/progenitoras también contribuye al proceso de envejecimiento reduciendo la regeneración y reparación de los tejidos $y$, en consecuencia, recortando la longevidad. Otro factor importante es la deposición intracelular de los gránulos de lipofuscina (pigmentos de la edad), un polimero no degradable concentrado en los lisosomas, que acelera los niveles de estrés oxidativo en las células seniles. Las drogas contribuyen en gran medida a estos factores de aceleración del envejecimiento en el cerebro. Se ha demostrado que la metilenedioximetanfetamina (éxtasis) y la metafentamina provocan deterioro del ADNmt. Con respecto a las células madre/progenitoras se ha visto que una serie de opiáceos y de psicoestimulantes, incluyendo el éxtasis, disminuyen la capacidad de regeneración del hipocampo al reducir la tasa de proliferación de los progenitores neuronales y/o al dañar la supervivencia a largo plazo de los precursores neuronales. El consumo crónico de alcohol potencia la deposición de lipofuscina en las neuronas y en las células del corazón. Estos hechos son claros signos de la capacidad de dichas drogas para acelerar el envejecimiento cerebral. El alcance y la gravedad de la contribución de las drogas a la aceleración del envejecimiento son inciertos, pero los supuestos efectos avejentadores se suman al lado oscuro de la adición a las drogas y exigen sin duda un mayor esfuerzo investigador en el futuro próximo.

Palabras clave: Drogas de abuso; envejecimiento; ADN mitocondrial; proliferación de células madre/progenitoras; lipofuscina.
REQUIMTE. Departmento de Toxicología. Facultad de Farmácia. Universidad de Porto.

Enviar correspondencia a:

Felix Carvalho. REQUIMTE. Departmento de Toxicologia. Facultad de Farmácia. Universidad de Porto. Rua Aníbal Cunha, 164, 4030-099 Porto, Portugal. Email: felixdc@ff.up.pt

\section{ABSTRACT}

The aging or senescence process that follows maturation is characterized by time-related functional decline due to genetic, biochemical, physiological and anatomical degeneration in tissues and organ systems with time. Oxidative damage to mitochondrial DNA (mtDNA) in the heart and brain is inversely related to maximum life span of mammals, suggesting that accumulation of mtDNA damage is involved in the various disorders associated with aging, cancer and neurodegeneration. The suppression of stem/progenitor cell proliferation also contributes to the aging process, by reducing tissue regeneration and repair and ultimately reducing longevity. Another important factor is the intracellular deposition of lipofuscin granules (age pigment), a non-degradable polymeric material accumulated within lysosomes, which ultimately exacerbate oxidative stress levels in senescent cells. Drugs of abuse can strongly contribute to these senescence accelerating factors in the brain. Methylenedioxymethamphetamine ("ecstasy") and methamphetamine were shown to promote deletions in brain mtDNA. Concerning stem/ progenitor cells, it has been shown that several opiates and psychostimulants, including ecstasy, decrease the self-renewal capacity of the hippocampus by diminishing the rate of proliferation of neural progenitors and/or by impairing the long-term survival of neural precursors. Chronic alcohol consumption induces lipofuscin deposition in neurons and heart cells. These facts provide interesting hints on the potential of these drugs in accelerating brain senescence. While the extent and severity of the contribution of drugs of abuse for accelerated senescence remain uncertain, these putative aging effects add up to the dark side of drug addiction and undoubtedly require a strong research effort in the near future.

Key words: Drugs of abuse; senescence; mitochondrial DNA; stem/progenitor cell proliferation; lipofuscin. 


\section{EL PROCESO DE ENVEJECIMIENTO}

E proceso de envejecimiento o senescencia que sigue a la madurez se caracteriza por una decadencia funcional vinculada a la edad y cuyo origen es la degeneración anatómica, fisiológica, bioquímica y genética de los tejidos y de los órganos. Se trata de un proceso inexorable provocado por causas intrínsecas (evolutivo-genéticas) y extrínsecas (estocásticas). El proceso evolutivo-genético del envejecimiento forma parte de la cadena de desarrollo genéticamente programada y controlada y de la madurez. El carácter estocástico del envejecimiento viene dado por el daño aleatorio de las moléculas vitales causado por factores ambientales (Troen, 2003). Y de hecho, las alteraciones estocásticas de estructuras y funciones generadas por la entropía molecular, la mutación, el estrés oxidativo y otros factores de deterioro biológico acumulado son causas fundamentales de envejecimiento (Carnes, Staats y Sonntag, 2008).

El daño tanto del ADN nuclear, que contiene la mayor parte de ARN celular y de proteínas, como del ADN mitocondrial contribuyen al proceso de envejecimiento (Lombard, Chua, Mostoslavsky, Franco, Gostissa y Alt, 2005). EI ADN mitocondrial (ADNmt) es muy sensible a agentes oxidantes causados por la carencia de histonas y de proteínas asociadas al ADN (Shigenaga, Hagen y Ames, 1994). De forma significativa, el daño oxidativo del ADNmt en el corazón y el cerebro es inversamente proporcional a la longevidad máxima de los mamíferos, lo cual indica que la acumulación de daño de ADNmt se relaciona con diversas enfermedades vinculadas al envejecimiento, el cáncer y la neurodegeneración (Yang, Weissman, Bohr y Mattson, 2008). La menor proliferación de células madre/progenitoras también contribuye al proceso de envejecimiento reduciendo la regeneración y reparación de los tejidos y, en consecuencia, recortando la longevidad (Rando, 2006; Warmer, 2006). Otro factor importante es la deposición intracelular de los gránulos de lipofuscina (pigmentos de la edad), un polímero no degradable concentrado en los lisosomas. Existen crecientes evidencias de que la lipofuscina obstaculiza la capacidad de degradación lisosomial, provocando así un agravamiento del deterioro acumulado a edades avanzadas, y acentúa los niveles de estrés oxidativo en las células senescentes debido a la abundancia de hierro redox activo (Terman y Brunk, 2004).

\section{Aceleración del proceso de envejecimiento por consumo de drogas.}

Las drogas de abuso tienen la capacidad de contribuir de forma significativa a un envejecimiento acelerado. En la literatura científica existen ejemplos ilustrativos de daño del ADNmt, efectos perjudiciales sobre las células progenitoras y deposición de lipofuscina.

Recientemente se ha demostrado que la exposición de una rata adolescente a una administración desenfrenada y neurotóxica de metilenedioximetanfetamina ("éxtasis») provoca un estado de estrés oxidativo en la mitocondria cerebral

\section{THE AGING PROCESS}

7 he aging or senescence process that follows maturation is characterized by time-related functional decline due to genetic, biochemical, physiological and anatomical degeneration in tissues and organ systems. It is an inexorable process caused by intrinsic (developmental-genetic) and extrinsic (stochastic) causes. The developmental-genetic process of aging is part of the genetically programmed and controlled continuum of development and maturation. The stochastic nature of ageing is distinguished by random damage to vital molecules caused by environmental factors (Troen, 2003). In fact, stochastic perturbations of structure and function generated by molecular entropy, mutation, oxidative stress, and other sources of accumulated biological damage are fundamental causes of aging (Carnes, Staats and Sonntag, 2008).

Damage to both nuclear DNA, encoding the vast majority of cellular RNA and proteins, and mitochondrial DNA seems to contribute to the aging process (Lombard, Chua, Mostoslavsky, Franco, Gostissa and Alt, 2005). Mitochondrial DNA (mtDNA) is particularly sensitive to oxidative agents due to the lack of protective histones and DNA-binding proteins (Shigenaga, Hagen and Ames, 1994). Interestingly, oxidative damage to mtDNA in the heart and brain is inversely related with maximum life span of mammals, suggesting that accumulation of mtDNA damage is involved in the various disorders associated with aging, cancer and neurodegeneration (Yang, Weissman, Bohr and Mattson 2008). The suppression of stem/progenitor cell proliferation also contributes to the aging process, by suppressing tissue stem/progenitor cell proliferation, thereby reducing tissue regeneration and repair and ultimately reducing longevity (Rando, 2006; Warmer 2006). Another important factor is the intracellular deposition of lipofuscin granules (age pigment), a non-degradable polymeric material accumulated within lysosomes. There is increasing evidence that lipofuscin hampers lysosomal degradative capacity, thus promoting the aggravation of accumulated damage at old age, and exacerbate oxidative stress levels in senescent cells, due to its richness in redoxactive iron (Terman and Brunk, 2004).

\section{Acceleration of the aging process by drug abuse}

Drugs of abuse have the potential to significantly contribute to accelerated aging. Illustrative examples for mtDNA damage, deleterious effects on progenitor cells, and lipofuscin deposition can be found in the literature.

It was recently demonstrated that the exposure of an adolescence rat model to a neurotoxic binge administration of methylenedioxymethamphetamine ("ecstasy") induces an oxidative stress status in brain mitochondria accompanied by deletion of mtDNA (Alves, Summavielle, Alves, Gomes- 
acompañado por deterioro del ADNmt (Alves, Summavielle, Alves, Gomes-da-Silva, Barata, Fernandes, et al. 2007). Asimismo, la metanfetamina produce un descenso en el número de copias de ADNmt y de proteinas mitocondriales por mitocondrio, además de apoptosis en la línea cellular SH-SY5Y del neuroblastoma dopaminérgico humano (Wu, Ping, Yen, Chang, Wang, Yeh, et al., 2007).

Con respecto a las células madre/progenitoras se ha demostrado que una serie de opiáceos y psicoestimulantes disminuyen la capacidad de renovación del hipocampo al reducir la tasa de proliferación de los progenitores neuronales y/o al dañar la supervivencia a largo plazo de los precursores neuronales (Eisch y Harburg, 2006; Hernández-Rabaza, Domínguez-Escribà, Barcia, Rosel, Romero, García-Verdugo, Canales et al., 2006; Poon, Vaishnav, Getchell, Getchell y Butterfield, 2007). El deterioro provocado por los opiáceos y los psicoestimulantes en la neurogénesis del hipocampo adulto tiene que ver con la duración del tratamiento, la dosis y la región del cerebro, y no cursa con muerte celular ni con la activación del eje del estrés (Eisch y Harburg, 2006). Por tanto, la influencia de estos efectos sobre la senescencia cerebral aún está por ver. El consumo desenfrenado o a largo de plazo de alcohol también produce el mismo efecto perjudicial (Nixon y Crews, 2002; Herrera, Yague, Johnsen-Soriano, Bosch-Morell, Collado-Morente, Muriach, et al., 2003), aunque las dosis moderadas de alcohol ejercen el efecto contrario al reforzar las tasas de proliferación de células progenitoras (Aberg, Hofstetter, Olson y Brené, 2005). Aparte del innegable impacto de estos descubrimientos en el conocimiento sobre la iniciación, mantenimiento y tratamiento de las adicciones a las drogas, proporcionan interesantes datos acerca de la capacidad de dichas drogas para acelerar la senescencia del cerebro.

Se ha demostrado que la ingesta crónica de etanol provoca una deposición progresiva de la lipofuscina en las neuronas del hipocampo de las ratas (Borges, Paula-Barbosa y Volk1986), en las células cerebelosas de Purkinje (Lewandowska, Kujawa y Jedrzejewska, 1994), y en las neuronas simpáticas periféricas de las ratas (Jaatinen, Kiianmaa y Hervonen, 1992), un proceso que convive con pérdida de neuronas provocada por el etanol y con sinapsis (Paula-Barbosa, Brandão, Madeira y Cadete-Leite, 1993). Curiosamente, en fecha reciente se ha demostrado que los antioxidantes del vino tinto protegen las neuronas del hipocampo de las ratas del daño crónico provocado por el etanol, asociado a la deposición de lipofuscina (Assunção, Santos-Marques, de Freitas, Carvalho, Andrade, Lukoyanov, et al., 2007). En los alcohólicos humanos es corriente la deposición de la lipofuscina del miocardio (Jaatinen, Saukko y Hervonen, 1993) y la lipofuscinosis ceroidea en la fibrosis hepatica alcohólica (Kishi, Maeyama, Koike, Aida, Yoshida y Uchikoshi, 1996).
da-Silva, Barata, Fernandes, et al., 2007). Methamphetamine was also shown to induce a decrease in mtDNA copy number and mitochondrial proteins per mitochondrion, as well as apoptosis in a human dopaminergic neuroblastoma SH-SY5Y cell line (Wu, Ping, Yen, Chang, Wang, Yeh, et al., 2007).

Concerning stem/progenitor cells, it has been shown that several opiates and psychostimulants decrease the self-renewal capacity of the hippocampus by diminishing the rate of proliferation of neural progenitors and/or by impairing the long-term survival of neural precursors (Eisch and Harburg, 2006; Hernández-Rabaza, DomínguezEscribà, Barcia, Rosel, Romero, García-Verdugo, Canales, et al, 2006; Poon, Vaishnav, Getchell, Getchell and Butterfield, 2007). Opiate- and psychostimulant-induced impairment of adult hippocampal neurogenesis appears to be treatment duration-, dose-, and brain region-specific, and not accompanied by cell death or linked to activation of the stress axis (Eisch and Harburg, 2006). Therefore, the influence of these effects on brain senescence still needs clarification. Long term or binge administration of alcohol also resulted in the same deleterious effect (Nixon and Crews, 2002; Herrera, Yague, Johnsen-Soriano, Bosch-Morell, Collado-Morente, Muriach, et al., 2003), though moderate doses of alcohol had the opposite effect, by enhancing the proliferation rates of progenitor cells (Aberg, Hofstetter, Olson and Brené, 2005). Besides the important impact of these findings in the knowledge about the initiation, maintenance, and treatment of drug addiction, they also provide interesting hints on the potential of these drugs in accelerating brain senescence.

Chronic ingestion of ethanol has been shown to result in a progressive deposition of lipofuscin in rat hippocampal neurons (Borges, Paula-Barbosa and Volk, 1986), rat cerebellar Purkinje cells (Lewandowska, Kujawa and Jedrzejewska, 1994), and rat peripheral sympathetic neurons (Jaatinen, Kiianmaa and Hervonen, 1992), a process that can underlie the ethanol-induced loss of neurons and synapses (Paula-Barbosa, Brandão, Madeira and Cadete-Leite, 1993). Curiously, it was recently shown that red wine antioxidants protect rat hippocampal neurons against chronic ethanol induced damage associated with lipofuscin deposition (Assunção, Santos-Marques, de Freitas, Carvalho, Andrade, Lukoyanov, et al., 2007). In human alcoholics, deposition of myocardial lipofuscin (Jaatinen, Saukko and Hervonen, 1993), and ceroid-lipofuscinosis in alcoholic liver fibrosis (Kishi, Maeyama, Koike, Aida, Yoshida and Uchikoshi,1996), seem to be common.

\section{ACCELERATED AGING SIGNS AMONG DRUG ABUSERS}

Beyond the high mortality rates due to overdose and infectious diseases, the long-term physical effects of drug
Aunque las sobredosis y las enfermedades infecciosas provocan altas tasas de mortalidad, los efectos físicos a largo

\section{SIGNOS DE ENVEJECIMIENTO ACELERADO EN LOS CONSUMIDORES DE DROGAS.}


plazo del consumo de drogas se fraguan en las etapas iniciales de la adición. Además, se aceleran la generación y progresión de una serie enfermedades relacionadas con la edad, que se caracterizan por niveles considerables de morbilidad. El consumo de anfetaminas y cocaína provocan a menudo complicaciones cardiovasculares como arritmias e infarto de miocardio en adictos jóvenes, mientras que el consumo a largo plazo predispone a la arterioesclerosis prematura, a hipertrofia ventricular y a cardiomiopatía (Dowling, Weiss y Condon, 2008). Por otro lado, el consumo de drogas ilegales agrava el deterioro de la función renal que se produce con la edad, como ha demostrado un estudio de Vupputuri y colaboradores (Vupputuri, Batuman, Muntner, Bazzano, Lefante, Whelton, et al., 2004), según el cual el riesgo de enfermedades renales leves era tres veces mayor entre los consumidores de cocaina y de crack y cuatro veces mayor entre los que tomaban drogas psicodélicas.

Con respecto a los problemas de salud mental, el espectro de consecuencias negativas va desde alteraciones emocionales, perceptivas o cognitivas que duran un tiempo limitado -como ocurre con el deterioro provocado por el éxtasis en la memoria asociativa, visual y verbal-, a verdaderos episodios de enfermedad psiquiátrica, como en el caso de las psicosis relacionadas con la metanfetamina y el cannabis (Chen y Lin, 2009). A pesar de las dificultades para realizar estudios entre seres humanos consumidores de drogas, la gran mayoría de investigaciones sobre el éxtasis proporcionan datos que demuestran que esta droga posee una elevada capacidad para provocar y acelerar déficits irreversibles en la función cognitiva cerebral (Capela, Carmo, Remião, Bastos, Meisel y Carvalho, 2009). El cerebro de los sujetos dependientes de la cocaína muestra un elevado número de lesiones de materia blanca asociadas a la edad, aunque también podrían tener que ver con anormalidades cognitivas. En este caso, los déficits serian más abundantes entre los adictos en proceso de envejecimiento que entre adultos normales (Bartzokis, Beckson, Hance, Lu, Foster, Mintz, et al., 1999a; Bartzokis, Goldstein, Hance, Beckson, Shapiro, Lu, et al., 1999b). De igual modo, la disminución asociada a la edad de la ligazón del receptor de dopamina (Volkow, Logan, Fowler, Wang, Gur, Wong, et al., 2000) se ha relacionado con reducciones metabólicas vinculadas a la edad en el córtex frontal y en el giro cingular anterior, similares a las observadas en los consumidores de cocaína (Volkow, Fowler, Wang, Hitzemann, Logan, Schlyer, et al., 1993). También se ha demostrado que la metanfetamina daña los terminales monoaminérgicos y los transportadores del cuerpo estriado, tanto en seres humanos como en animales de laboratorio (Volkow, Chang, Wang, Fowler, Leonido-Yee, Franceschi, et al., 2001). Teniendo en cuenta que la función del sistema dopaminérgico nigroestratial disminuye con la edad, se cree que el consumo de metanfetamina a edad temprana aumenta el riesgo de padecer déficits motores de tipo parkinsoniano con la edad (Volkow, Chang, Wang, Fowler, Leonido-Yee, Franceschi, et al., 2001).

La dependencia de los opiáceos es una de las adiciones que más marcan. Los individuos de mediana edad con dependencia previa de opiáceos tienen menor calidad de salud física y psi- abuse is often established at early stages of addiction. In addition, age-related generation and progression of several diseases is likely to be accelerated and characterized by considerable levels of morbidity. Amphetamine and cocaine abuse often lead to cardiovascular complications such as arrhythmias and myocardial infarction in young addicts, while long-term abuse may also predispose to premature atherosclerosis, ventricular hypertrophy, and cardiomyopathy (Dowling, Weiss and Condon, 2008). Furthermore, illicit drug abuse may also exacerbate declines in kidney function that frequently occur with increasing age, as demonstrated in a study performed by Vupputuri and collaborators (Vupputuri, Batuman, Muntner, Bazzano, Lefante and Whelton, et al., 2004), in which the risk for mild kidney disease was three times greater among cocaine and crack users and four times greater among users of psychedelic drugs.

Regarding mental health problems, the spectrum of adverse health consequences extends from relatively timelimited emotional, perceptual or cognitive disturbances, as it happens with ecstasy-related decline in associative, visual, and verbal memory, to full-blown episodes of psychiatric disorder, as is the case of methamphetamine and cannabis-related psychosis (Chen and Lin, 2009). Despite difficulties in conducting studies in human drug abusers, the vast majority of studies related to ecstasy also provide data to support the idea that this drug has a high potential to induce and accelerate irreversible deficits in brain cognitive function (Capela, Carmo, Remião, Bastos, Meisel and Carvalho, 2009). The brains of cocaine-dependent subjects exhibit an increased number of age-related white matter lesions, thought to be linked to cognitive abnormalities. If so, these deficits would be more prevalent among aging addicts as compared with normal older adults (Bartzokis, Beckson, Hance, Lu, Foster, Mintz, et al., 1999a; Bartzokis, Goldstein, Hance, Beckson, Shapiro, Lu, et al., 1999b). Similarly, age-related decreases in dopamine receptor binding (Volkow, Logan, Fowler, Wang, Gur, Wong, et al., 2000) have been correlated with age-linked metabolic reductions in the frontal cortex and anterior cingulate gyrus, similar to that observed in cocaine abusers (Volkow, Fowler, Wang, Hitzemann, Logan, Schlyer, et al., 1993). It has also been demonstrated that methamphetamine damages monoaminergic terminals and transporters in the striatum, both in humans and laboratory animals (Volkow, Chang, Wang, Fowler, LeonidoYee, Franceschi, et al., 2001). Considering that the function of the nigrostriatal dopamine system decreases with age, it has been suggested that methamphetamine abuse early in life may increase risk for development of parkinsonianlike motor deficits with age (Volkow, Chang, Wang, Fowler, Leonido-Yee, Franceschi, et al., 2001).

Opiate dependence is perhaps one of the most stigmatizing addictions. Middle age individuals with previous opiate dependence have lower physical and psychological health-related quality of life than the general population. A paradigmatic example reported in a recent study (Rosen, Smith and Reynolds, 2008) performed in a 
cológica que la población general. Un ejemplo paradigmático presentado en un reciente estudio (Rosen, Smith y Reynolds. 2008) que se realizó sobre una muestra de 140 pacientes tratados con metadona de 50 años (entrevistas personales) mostró que más de la mitad $(57,1 \%)$ de los investigados habian tenido al menos una patología mental en el año anterior. En el año previo a la entrevista la enfermedad mental más abundante entre los pacientes adultos de mayor edad fue el episodio depresivo mayor (32,9\%). Las alteraciones de ansiedad más abundantes fueron el sindrome de estrés postraumático $(27,8 \%)$ y el sindrome de ansiedad generalizada $(29,7 \%)$. Como dato adicional, las mujeres sufrieron niveles mucho más altos de depresión que los hombres (43,8\% frente a 27,2\%) y casi el doble de tasa de prevalencia de agorafobia y trastornos de pánico. Con respecto a la salud física, los entrevistados presentaron altas tasas de problemas de salud en el año anterior, entre ellos artritis (54,3\%) e hipertensión (44,9\%). La mayoría de los entrevistados afirmaron que tenían una salud regular 0 mala $(57,7 \%)$.

Con respecto al consumo y dependencia del alcohol, como se ha observado recientemente (Guardia, 2008; Schuckit, 2009), adelantan la aparición de cardiopatías, hipertensión, accidente cerebrovascular hemorrágico, cáncer y cirrosis hepática, pues afectan al sistema cardiovascular, al gastrointestinal y al inmune, y pueden provocar neuropatía periférica, encefalopatía alcohólica, deterioro cognitivo e incluso demencia alcohólica.

\section{CONCLUSIONES}

El alcance y la gravedad de la contribución de las drogas de abuso al envejecimiento acelerado son inciertos, pero los supuestos efectos avejentadores se suman al lado oscuro de la adición a las drogas y exigen sin duda un mayor esfuerzo investigador en el futuro próximo. A la hora de responder a la pregunta de si existe envejecimiento precoz entre los consumidores de drogas de abuso, me viene a la mente la famosa frase de la canción de Bob Dylan: "The answer, my friend, is blowing in the wind (la respuesta, amigo, está en el viento)"

\section{REFERENCIAS / REFERENCES}

Aberg, E., Hofstetter, C. P., Olson, L. y Brené, S. (2005). Moderate ethanol consumption increases hippocampal cell proliferation and neurogenesis in the adult mouse. International Journal of Neuropsychopharmacology, 8: 557-67.

Alves, E., Summavielle, T., Alves, C. J. Gomes-da-Silva, J., Barata, J. C., Fernandes, E., et al. (2007). Monoamine oxidase-B mediates ecstasy-induced neurotoxic effects to adolescent rat brain mitochondria. Journal of Neuroscience, 27: 10203-10.

Assunção, M., Santos-Marques, M. J., de Freitas, V., Carvalho, F., Andrade, J. P., Lukoyanov, N. V. y Paula-Barbosa, M. M. (2007). Red wine antioxidants protect hippocampal neurons against clinic sample of 140 adult methadone patients over the age of 50 (face-to-face interviews) showed that over half $(57.1 \%)$ of respondents had at least one mental health disorder in the past year. In the year before the interview, the most prevalent mental health disorder experienced by older adult patients was major depressive episode (32.9\%). The most prevalent anxiety disorders were posttraumatic stress disorder (27.8\%) and generalized anxiety disorder (29.7\%). Additionally, women experienced significantly higher levels of depression than men (43.8\% versus $27.2 \%$ ), and nearly twice the prevalence rate of agoraphobia and panic disorders. Regarding physical health, respondents reported high rates of health problems in the past year, including arthritis (54.3\%) and hypertension (44.9\%). The majority of respondents reported having fair to poor physical health (57.7\%).

Referring to alcohol abuse and dependence, as recently reviewed (Guardia, 2008; Schuckit, 2009), it shortens the onset of heart disease, hypertension, hemorragic stroke, cancers, and liver cirrhosis, by affecting the cardiovascular, gastrointestinal, and immune systems, and may cause peripheric neuropathy, alcoholic encephalopathies, and cognitive impairment that can even lead to alcoholic dementia.

\section{CONCLUSIONS}

While the extent and severity of the contribution of drugs of abuse for accelerated senescence remain uncertain, these putative aging effects add up to the dark side of drug addiction and undoubtedly require a strong research effort in the near future. Answering the question of how bad is accelerated senescence in consumers of drugs of abuse, it comes to my mind a famous phrase in a Bob Dilan's song: "the answer, my friend, is blowing in the wind".

ethanol-induced damage: a biochemical, morphological and behavioral study. Neuroscience, 146: 1581-92.

Bartzokis, G., Beckson, M., Hance, D. B., Lu, P. H., Foster, J. A., Mintz, J., et al. (1999a). Magnetic resonance imaging evidence of "silent" cerebrovascular toxicity in cocaine dependence. Biological Psychiatry, 45: 1203-11.

Bartzokis, G., Goldstein, I. B, Hance, D. B., Beckson, M., Shapiro, D., Lu, P. H., et al. (1999b). The incidence of T2-weighted MR imaging signal abnormalities in the brain of cocaine-dependent patients is age-related and region-specific. American Journal of Neuroradiology, 20: 1628-35.

Borges, M. M., Paula-Barbosa, M. M. y Volk, B. (1986). Chronic alcohol consumption induces lipofuscin deposition in the rat hippocampus. Neurobiology of Aging, 7: 347-55. 
Capela, J. P., Carmo, H., Remião, F., Bastos, M. L., Meisel, A. y Carvalho, F. (2009). Molecular and Cellular Mechanisms of EcstasyInduced Neurotoxicity: An Overview. Molecular Neurobiology, 39: 10-71 (DOI: 10.1007/s12035-009-8064-1).

Carnes, B. A., Staats, D. O. y Sonntag, W. E. (2008). Does senescence give rise to disease? Mechanisms of Ageing and Development, 129: 693-9.

Chen, C. Y. y Lin, K. M. (2009). Health consequences of illegal drug use. Current Opinion in Psychiatry, 22: 287-92.

Dowling, G. J., Weiss, S. R. y Condon, T. P. (2008). Drugs of abuse and the aging brain. Neuropsychopharmacology, 33: 209-18.

Eisch, A. J. y Harburg, G. C. (2006). Opiates, psychostimulants, and adult hippocampal neurogenesis: Insights for addiction and stem cell biology. Hippocampus, 16: 271-86.

Hernández-Rabaza, V., Dominguez-Escribà, L., Barcia, J. A., Rosel, J. F., Romero, F. J., García-Verdugo, J. M. y Canales, J. J. (2006). Binge administration of 3,4-methylenedioxymethamphetamine ("ecstasy") impairs the survival of neural precursors in adult rat dentate gyrus. Neuropharmacology, 51: 967-73.

Herrera, D. G., Yague, A. G., Johnsen-Soriano, S., Bosch-Morell, F., Collado- Morente, L., Muriach, M., Romero, F. J. y GarciaVerdugo, J. M. (2006). Selective impairment of hippocampal neurogenesis by chronic alcoholism: protective effects of an antioxidant. Proceedings National Academy of Sciences USA, 100: 7919-24.

Jaatinen, P., Kiianmaa, K. y Hervonen, A. (1992). Lifelong ethanol consumption enhances the age-related changes in rat sympathetic neurons. Mechanisms of Ageing and Development, 63: 193-5.

Jaatinen, P., Saukko, P. y Hervonen, A. (1993). Chronic ethanol exposure increases lipopigment accumulation in human heart. Alcohol and Alcoholism; 28: 559-69.

Kishi, M., Maeyama, S., Koike, J., Aida, Y., Yoshida, H. y Uchikoshi T. (1996). Correlation between intrasinusoidal neutrophilic infiltration and ceroid-lipofuscinosis in alcoholic liver fibrosis with or without fatty change: clinicopathological comparison with nutritional fatty liver. Alcoholism Clinical Experimental Research, 20: 366A-370A.

Lewandowska, E., Kujawa, M., Jedrzejewska, A. (1994). Ethanol-induced changes in Purkinje cells of rat cerebellum. II. The ultrastructural changes after chronic ethanol intoxication. (Morphometric evaluation). Folia Neuropathology, 32: 61-64.

Lombard, D. B., Chua, K. F., Mostoslavsky, R., Franco, S., Gostissa, M. y Alt, F. W. (2005). DNA repair, genome stability, and aging. Cell; 120: 497-512.

Nixon, K., Crews, F. T. (2002). Binge ethanol exposure decreases neurogenesis in adult rat hippocampus. Journal of Neurochemistry; 83: 1087-93.

Paula-Barbosa, M. M., Brandão, F., Madeira, M. D. y Cadete-Leite, A. (1993). Structural changes in the hippocampal formation after long-term alcohol consumption and withdrawal in the rat. Addiction, 88: 237-47.

Poon, H. F., Vaishnav, R. A., Getchell, T. V., Getchell, M. L. y Butterfield, D. A. (2006). Quantitative proteomics analysis of differential protein expression and oxidative modification of specific proteins in the brains of old mice. Neurobiology of Aging, 27: 1010-9.

Rando, T. A. (2006). Stem cells, ageing, and the quest for immortality. Nature, 441: 1080-86.

Rosen, D., Smith, M. L., Reynolds y C. F. (2008). 3rd. The prevalence of mental and physical health disorders among older methadone patients. American Journal of Geriatric Psychiatry, 16: 488-497.

Guardia, J. (2008). ¿Es bueno el alcohol para la salud? Adicciones, 20: 221-35.

Shigenaga, M. K., Hagen, T. M. y Ames, B. N. (1994). Oxidative damage and mitochondrial decay in aging. Proceeding of the National Academy of Sciences of USA, 91: 10771-78.

Schuckit, M. A. (2009). Alcohol-use disorders. Lancet, 373: 492-501.

Terman, A., Brunk, U. T. (2004). Aging as a catabolic malfunction. International Journal of Biochemistry \& Cell Biology, 36: 2365-75.

Troen, B. R. (2003). The biology of aging. Mt Sinai Journal of Medicine, $70: 3-22$.

Warner, H. R. (2007). 2006 Kent award lecture: is cell death and replacement a factor in aging? Journal of Gerontology. $A$, Biologycal Sciences and Medical Sciences, 62: 1228-32.

Wu, C. W., Ping, Y. H., Yen, J. C., Chang, C. Y., Wang, S. F., Yeh, C. L., et al. (2007). Enhanced oxidative stress and aberrant mitochondrial biogenesis in human neuroblastoma SH-SY5Y cells during methamphetamine induced apoptosis. Toxicology Applied Pharmacology, 220: 243-51.

Volkow, N. D., Fowler, J. S., Wang, G. J., Hitzemann, R., Logan, J., Schlyer DJ et al. (1993). Decreased dopamine D2 receptor availability is associated with reduced frontal metabolism in cocaine abusers. Synapse, 14: 169-177.

Volkow, N. D., Logan, J., Fowler, J. S., Wang, G. J., Gur, R. C., Wong, C. et al. (2000). Association between age-related decline in brain dopamine activity and impairment in frontal and cingulated metabolism. American Journal of Psychiatry, 157: 75-80.

Volkow, N. D., Chang, L., Wang, G. J., Fowler, J. S., Leonido-Yee, M., Franceschi, D., et al. (2001). Association of dopamine transporter reduction with psychomotor impairment in methamphetamine abusers. American Journal of Psychiatry, 158: 377-382.

Vupputuri, S., Batuman, V., Muntner, P., Bazzano, L. A., Lefante, J. J, Whelton, P. K., et al. (2004). The risk for mild kidney function decline associated with illicit drug use among hypertensive men. American Journal of Kidney Disease, 43: 629-635.

Yang, J. L., Weissman, L., Bohr, V. A. y Mattson, M. P. (2008). Mitochondrial DNA damage and repair in neurodegenerative disorders. DNA Repair (Amst), 7: 1110-20 